\title{
PHYSICAL ACTIVITY MODEL TO DEVELOP BASIC MOVEMENT SKILLS IN KINDERGARTEN STUDENTS BASED ON PHYSICAL LITERACY
}

\author{
Aris Fajar Pambudi ${ }^{1,2 A B C D E}$, Sugiyanto ${ }^{1 \mathrm{ACDE}}$, \\ Furqon Hidayatullah $^{1 \mathrm{ABCE}}$, Sapta Kunta Purnama ${ }^{1 \mathrm{BCDE}}$ \\ ${ }^{1}$ Sebelas Maret University \\ ${ }^{2}$ Yogyakarta State University \\ Authors' Contribution: A - Study design; B - Data collection; C - Statistical analysis; D - Manuscript Preparation; E - Funds Collection
}

Corresponding Author: Aris Fajar Pambudi, E-mail: arisfajarpambudi@student.uns.ac.id Accepted for Publication: October 28, 2021

Published: December 25, 2021

DOI: $10.17309 / \mathrm{tmfv} .2021 .4 .06$

\begin{abstract}
The lack of physical activity that is applied in Kindergarten (PAUD) has a bad impact on the future of children. It was revealed that the designed curriculum was more dominant in the development of academic achievement.

The study purpose was to develop basic movement skills in kindergarten students based on physical literacy.

Materials and methods. The method used in this study was research and development methods using quantitative and qualitative settings. With a population of all kindergarten teachers in Cilacap Regency which amounted to 1,387 teachers from 350 kindergartens, the sample used was 52 teachers who were taken by proportional sampling. The data analysis technique used in his study was descriptive quantitative data analysis techniques with percentages. Results. The research findings show that each item of the statement of physical activity variables in developing students' basic movements can be seen from the average value of 4.205 which is in the very good category scale range. The statement that has the smallest average value in statement number 2 is "Do students have enough physical activity at school?" and has a value of 3.827 with a good category. While the highest average in statement number 1 is "Are Kindergarten students' physical activities held at school?" with an average value of 4.423 very good category. Conclusions. Therefore, it can be concluded that "kindergarten students' physical activities held in schools" give a very good impression and are beneficial for kindergarten (PAUD) children for their growth and development. Keywords: physical activity, basic movement skills, kindergarten, physical literacy.
\end{abstract}

\section{Introduction}

Kindergarten education is non-formal education organized in an effort to help in laying the foundation for development in all aspects before entering school. Preschool age is a sensitive age to receive stimuli and is very decisive for the development of children in the future Suherman (2017). Early childhood can be said to be the phase of the early years of life, the biggest role and responsibility lies with parents and the role of pre-school education and Kindergarten Arsana et al. (2019). According to Pangrazi and Beighle (2019), physical education taught to children before basic education will be able to assist in controlling aspects of emotional development, and can stimulate children's growth and development. Preschool education is one form of education as a basis for shaping physical growth and development (gross

(C) Pambudi, A.F., Sugiyanto, S., Hidayatullah, F., \& Purnama, S.K., 2021. and fine motion), cognitive (creativity, emotional intelligence, and spiritual intelligence), social emotional (attitudes and behaviour), language and communication, so it can be concluded that the goal to be achieved is to develop all potential from an early age, so that children develop naturally (Hijriati, 2019). Physical activity can be considered for children as an exercise to strengthen their muscle (Nasrulloh et al., 2020).

Putra, Gustiawati and Julianti (2020) in the practice of physical education, early childhood faces various problems from learning activities, facilities, social conditions and government policies that pay less attention to early childhood physical education. Kindergarten curriculum, states that physical or physical activity is the scope of physical learning programs, sports and health. For students in kindergarten, the form of physical activity that is packaged in the form of play is very important (Sutapa et al, 2020). The tendency of children at this time to experience limitations in movement. Children are more engrossed in their gadgets, more 
engrossed in games or fond of fast food. The causes of overweight and obesity in children are complex. This is confirmed by a study conducted in the United States. Obesity data in the United States from year to year for ages 2-19 years (Skinner et al. 2018).This is in line with previous literature studies. The initial study was conducted by conducting interviews and direct observations with teachers. From the results of interviews and observations made, it was revealed that the curriculum designed was more dominant in the development of academic achievement (Kremer et al. 2016).

Basic movements (fundamental motor skills) which are sought to be learned through physical education. According to Sun and Shen (2017), skills that form the basis of human movement. Ideally, family planning/kindergarten children are given sufficient basic movement experience in accordance with their stage of growth and physical development as well as providing sufficient movement provisions for children to have good mastery of movement. One of the efforts to overcome movement problems for children is to create a correct concept map of the movements that children must do, namely by introducing movement through the concept of physical literacy.

Physical literacy provides insight, experience, competence, motivation in children so that children have sufficient "treasury" of movement as provisions for later active life throughout life. In other words, physical literacy aims to provide movement choices so that they have a lot of movement "vocabulary". One solution that can be done is to develop a physical activity model for kindergarten students based on physical literacy. The results of the product will be packaged in the form of a manual, that it is easy for teachers to understand and implement at school. Donnelly et al. (2016), stated the results of a national study in Australia, showing that the level of physical fitness is significantly correlated with academic achievement. Another opinion was also conveyed by Marttinen et al. (2017), that increasing the level of physical activity has a mutually beneficial effect on the health and academic achievement of students. In addition, participa-

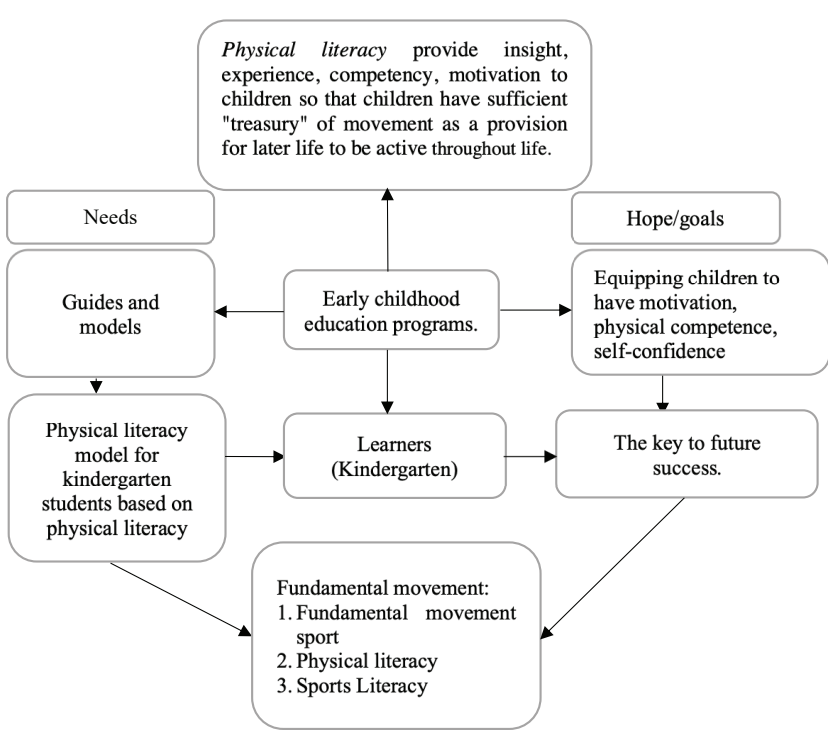

Fig. 1. Conceptual framework Physical activity to develop basic movement skills for kindergarten students based on physical literacy tion in programmed physical activity can improve academic achievement and brain performance, such as: attention and memory. In addition, it will also focus on doing assignments in class and improve the learning experience (Brusseau \& Hannon, 2015).

Based on explanation above, to avoid the lack of physical activity in Kindergarten that has a bad impact on the future of children, researchers develop a model to increase the physical activity based on physical literacy. Hopefully, this model can be a role as a balancing part between the development of academic achievement (cognitive) and the development of student's psychomotor. The remaining of this paper is organized as follows. Section 2 reviews all materials and methods. Section 3 presents the result. Section 4 presents the discussion about this study and finally Section 5 concludes with some direction for future work.

\section{Materials and methods}

\section{Study participants}

The population in this quantitative research is all kindergarten teachers in Cilacap Regency, totalling 1387 teachers from 350 kindergartens, the sample used is 52 teachers taken by proportional sampling.

\section{Study organization}

This study uses research and development methods. According to Kristiyanto et al. (2020), there are 10 steps that must be taken in conducting research and development. These steps can be easily seen in the figure as follow:

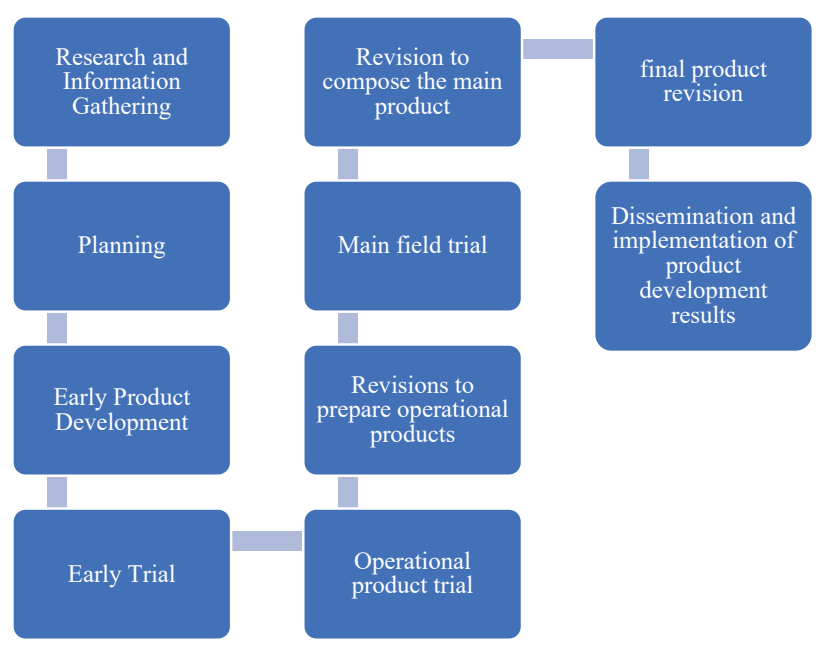

Fig. 2. Research and Development Steps

This study uses quantitative and qualitative methods. The research instruments used in the study were questionnaires, interviews and document studies. Questionnaires are used to determine the needs of kindergarten in learning activities, especially for physical motoric material. Interviews were used to find out the detail of learning implementation in kindergarten. Document Study was used to examine the learning documents in kindergarten such as curriculum, time allocation, and learning facilities. 


\section{Statistical analysis}

The data analysis technique in this study used descriptive quantitative data analysis techniques with percentages. The method of calculating data analysis is to find the magnitude of the relative frequency of the percentage with the following formula:

$$
\begin{array}{ll}
P=\frac{\mathrm{F}}{\mathrm{N}} \times 100 \% & \begin{array}{l}
\text { Description } \\
\mathrm{P}=\text { Percentage searched } \\
\mathrm{F}=\text { Frequency }
\end{array} \\
\mathrm{N}=\text { Number of Respondents }
\end{array}
$$

Fig. 3. Quantitative descriptive data analysis techniques

Test the validity in the assessment using Aiken's Content validity. This test is to determine the level of item validity between ratters with the formula used.

$$
\begin{aligned}
& \mathrm{s}=\mathrm{r}-\mathrm{lo} \\
& \mathrm{r}=\text { the number given by the ratter } \\
& v=\sum s /[n(c-1)] \quad \text { lo }=\text { number of low validity values } \\
& \mathrm{n} \text { = number of appraisers } \\
& \text { c = highest validity rating score }
\end{aligned}
$$

Fig. 4. Validity test with content validity Aiken

Reliability test in the assessment of the draft model using Cronbach's Alpha. This assessment is to test whether the assessment between the averages has a level of consistency with Cronbach's Alpha formula as follows:

$$
\begin{aligned}
\text { Description } & \\
r_{11}=\left(\frac{\mathrm{n}}{\mathrm{n}-1}\right)\left(1 \frac{\sum \sigma_{\mathrm{t}}^{2}}{\mathrm{n}-\sigma_{\mathrm{t}}^{2}}\right) & \mathrm{n} \quad=\text { sought reliability } \\
\sum \sigma_{\mathrm{t}}^{2} & =\text { total variance score for each item } \\
\sigma_{\mathrm{t}}^{2} & =\text { total variance }
\end{aligned}
$$

Fig. 5. Reliability test using Alpha Cronbach

\section{Results}

Research data for each question item obtained from questionnaires collected from 52 respondents. The measurement scale used in this study is a Likert scale. Researchers use this scale for this study because the distance or Likert between levels is clear, Data categories have logical rules. Scoring on this Likert scale starting from numbers 1 to 5 with ratings. Therefore, the average categorization of each item of research questions is as follows.

Based on table 1 above, with a sample of 52 people obtained a minimum value of 2.78 , maximum value of 5.00 ,

Table 1. Result Description of Physical Activity

\begin{tabular}{lcccccc}
\hline & N & Min & Max & Mean & SD & description \\
\hline Physical Activity & 52 & 2.78 & 5.00 & 4.25 & .471 & very good \\
Valid N (listwise) & 52 & & & & & \\
\hline
\end{tabular}

with a mean value of 4.20 , Std. Deviation .471 with the description "very good".

Table 2. Kindergarten students' physical activities are held in schools?

\begin{tabular}{ccccc}
\hline & Frequency & Percent & Valid Percent & $\begin{array}{c}\text { Cumulative } \\
\text { Percent }\end{array}$ \\
\hline Valid NT & 5 & 9.6 & 9.6 & 9.6 \\
S & 20 & 38.5 & 38.5 & 48.1 \\
SS & 27 & 51.9 & 51.9 & 100.0 \\
Total & 52 & 100.0 & 100.0 & \\
\hline
\end{tabular}

\begin{tabular}{|c|c|c|c|c|c|}
\hline & & Frequency & Percent & Valid Percent & $\begin{array}{c}\text { Cumulative } \\
\text { Percent }\end{array}$ \\
\hline \multirow[t]{5}{*}{ Valid } & TS & 1 & 1.9 & 1.9 & 1.9 \\
\hline & NT & 4 & 7.7 & 7.7 & 9.6 \\
\hline & S & 25 & 48.1 & 48.1 & 57.7 \\
\hline & SS & 22 & 42.3 & 42.3 & 100.0 \\
\hline & Total & 52 & 100.0 & 100.0 & \\
\hline
\end{tabular}

Form table 2 above, it can be seen that for Neutral (N) results the frequency is 5, 9.6 for percent, 9.6 for valid percent and cumulative percent is 9.6 then, for the Agree (S) results obtained, the frequency is 20 , percent 38.5 , valid percent 38.5 and, cumulative percent 48.1. Furthermore, for the results strongly agree (SS) the frequency obtained is 27 , percent 51.9, valid percent 51.9, and cumulative percent is 100.0 .

Table 3. Specific allocations provided in the curriculum?

Table 3 shows the results of the specific allocations provided in the curriculum? with answer Disagree (TS), the frequency obtained is 1 , percent is 1.9 , valid percent is 1.9 , and cumulative percent is 1.9. Neutral (NT) obtained frequency as much as 4 , percent with a value of 7.7, valid percent 7.7, and cumulative percent 9.6. Agree (S) obtained a frequency of 25 , with a percent of 48.1 , valid percent of 48.1 , and cumulative percent of 57.7. Strongly agree (SS) with a frequency of 22 , the percent result is 42.3 , the valid percent is 42.3 , and the cumulative percent is 100.0 .

Table 4. Is the basic movement material delivered in teaching and learning?

\begin{tabular}{llcccc}
\hline & & Frequency & Percent & Valid Percent & $\begin{array}{c}\text { Cumulative } \\
\text { Percent }\end{array}$ \\
\hline Valid & TS & 1 & 1.9 & 1.9 & 1.9 \\
& NT & 4 & 7.7 & 7.7 & 9.6 \\
S & 27 & 51.9 & 51.9 & 61.5 \\
SS & 20 & 38.5 & 38.5 & 100.0 \\
Total & 52 & 100.0 & 100.0 & \\
\hline
\end{tabular}

In table 4, the results obtained from the question whether basic movement material is conveyed in teaching? for results Disagree (TS) obtained frequency as much as 1, with 1.9 percent, valid percent of 1.9 , and cumulative percent of 
1.9. For Neutral (NT) the frequency is 4 , with a percent of 7.7 , with a valid percent of 7.7, and cumulative percent of 9.6. In Agree (S) the frequency obtained is 27, with a percent of 51.9, a valid percent of 51.9, and a cumulative percent of 61.5. In strongly agree (SS) obtained a frequency of 20, with a percent of 38.5 , valid percent of 38.5 , and cumulative percent of 100.0 .

Table 5. The role of parents in monitoring student movement?

\begin{tabular}{|c|c|c|c|c|c|}
\hline & & Frequency & Percent & Valid Percent & $\begin{array}{c}\text { Cumulative } \\
\text { Percent }\end{array}$ \\
\hline \multirow[t]{5}{*}{ Valid } & TS & 1 & 1.9 & 1.9 & 1.9 \\
\hline & NT & 12 & 23.1 & 23.1 & 25.0 \\
\hline & S & 26 & 50.0 & 50.0 & 75.0 \\
\hline & SS & 13 & 25.0 & 25.0 & 100.0 \\
\hline & Total & 52 & 100.0 & 100.0 & \\
\hline
\end{tabular}

In table 5 shows the results Disagree (TS) obtained frequency as much as 1 , with a percent of 1.9 , with a valid percent of 1.9, and cumulative percent of 1.9. In Neutral (NT) answers, the frequency is 12 , with a percent of 23.1, valid percent of 23.1, and cumulative of 25.0. In the Agree (S) answer, the frequency is 26 , with percent 50.0 , valid percent 50.0 , and cumulative percent 75.0 .

Table 6. Does the teacher have sufficient knowledge of physical/physical literacy?

\begin{tabular}{|c|c|c|c|c|c|}
\hline & & Frequency & Percent & Valid Percent & $\begin{array}{c}\text { Cumulative } \\
\text { Percent }\end{array}$ \\
\hline \multirow[t]{5}{*}{ Valid } & TS & 2 & 3.8 & 3.8 & 3.8 \\
\hline & NT & 4 & 7.7 & 7.7 & 11.5 \\
\hline & $\mathrm{S}$ & 24 & 46.2 & 46.2 & 57.7 \\
\hline & SS & 22 & 42.3 & 42.3 & 100.0 \\
\hline & Total & 52 & 100.0 & 100.0 & \\
\hline
\end{tabular}

Table 6 shows that for the disagree (TS) answer, the frequency is 2 , with the percent result of 3.8 , valid percent of 3.8 , and cumulative percent of 3.8. In Neutral (NT) answers, the frequency is 4 , with a percent result of 7.7 , valid percent of 7.7, and cumulative percent with a result of 11.5. For the Agree (S) answer, the frequency is 24 , with a percent of 46.2 , a valid percent of 46.2 , and a cumulative percent of 57.7. Meanwhile, for Strongly agree (SS) answers, the frequency is 22 , percent is 42.3 , valid percent is 42.3 , and cumulative percent is 100.0 .

In table 7 above with the question, is there a guide on physical activities, motoric, basic movement skills?

Table 7. Are there guidelines on basic motor skills physical activities?

\begin{tabular}{ccccc}
\hline & Frequency & Percent & Valid Percent & $\begin{array}{c}\text { Cumulative } \\
\text { Percent }\end{array}$ \\
\hline Valid Yes & 19 & 36.5 & 36.5 & 36.5 \\
No & 33 & 63.5 & 63,5 & 100.0 \\
Total & 52 & 100.0 & 100.0 & \\
\hline
\end{tabular}

For the answer yes, the frequency is 19 , the percent is 36.5 , the valid percent is 36.5 , and the cumulative percent is 36.5 .

Table 8. Do teachers need guidance on physical motor activities?

\begin{tabular}{ccccc}
\hline \multicolumn{4}{c}{ Frequency Percent Valid Percent } & $\begin{array}{c}\text { Cumulative } \\
\text { Percent }\end{array}$ \\
\hline Valid Yes & 52 & 100.0 & 100.0 & 100.0 \\
\hline
\end{tabular}

In table 8 , it can be seen the results of the answers to the questions do teachers need guidance on physical motor activities? The answer is Yes, with a frequency of 52, percent 100 , valid percent 100 , and cumulative 100.0 .

Table 9. Description

\begin{tabular}{ll}
\hline & \multicolumn{1}{c}{ Description } \\
\hline STS & Strongly disagree \\
TS & Disagree \\
NT & Neutral \\
S & Agree \\
SS & Strongly agree \\
\hline
\end{tabular}

\section{Discussion}

Physical education has an important role in the formation of a whole person because the purpose of physical education is very comprehensive, namely targeting the development of cognitive, affective, and psychomotor aspects of students. In addition, physical education has an objective to obtain better physical condition of the children (Nugroho et al., 2021). Kindergarten is the most important and busy period of growth. At this age, children already have the skills and abilities, although not maximal. The age of the child at this time is a fundamental phase that will determine his life in the future. Physical Literacy (PL) is a skill that must be possessed by students as a result of a shift in the learning achievement of physical education (Physical and Health Education). Physical literacy provides insight, experience, competence, motivation in children so that children have sufficient "treasury" of movement as provisions for later active life throughout life. In other words, physical literacy aims to provide movement choices so that they have a lot of movement "vocabulary". Formulation in the preparation of physical activity models in developing basic movements (Mashud \& Abdillah, 2021).

Relevant previous research by Ginanjar et al. (2020). Which discusses the sports education model based on basic movement skills with the aim of testing the difference in the effect of the Sport Education Model (SEM) or sports education model using racquet sports between students who have high Fundamental Movement Skills (FMS) and students who have low FMS on students' sports orientation Junior high school. The results of the study stated that there was an effect of SEM on students with high FMS and low FMS on sports orientation of junior high school students so that this study concluded that SEM had an influence on students' sports orientation. Competitiveness is the subscale that plays the most role in students' sports orientation. 
The next relevant previous research is by Andrian et al. (2020) with the title The effectiveness of motor learning models based on movement base games for elementary school students. Which aims to provide alternative learning models that can be chosen by teachers to learn basic movement skills in elementary schools, by discussing the effectiveness of implementing the learning model using MBG in physical education and health sports learning. The results showed that the quality of the learning process was included in the good category, while the learning outcomes before and after learning showed a significant increase $(\mathrm{p}<0.05)$. Thus it can be concluded that the MBG development model is effectively applied in learning physical education and health sports.

The last recent relevant previous research by Gustian, Supriatna, and Purnomo (2019) with the title of the effectiveness of modification of traditional games in the development of physical literacy in kindergarten children. This study aims to stimulate children to always be active, have the skills, knowledge, motivation and confidence to carry out physical literacy activities. The results of the study as a whole obtained a value of 10843 (3.02) at the first meeting and $11596(3.22)$ at the first meeting and there has been an increase of 753 points (0.21). This increase occurs because traditional games stimulate children to always actively carry out movement activities through playing. This shows that traditional games are effective in developing physical literacy in kindergarten children.

Based on the description above, the importance of physical activity for children to always be active. Ismoko and Putro (2016) states that the introduction of physical activity needs to be given from an early age. This opinion was also added by Haapala (2013), children who have high physical fitness and motor skills can improve their working memory and attention. Moreover, Pusari, and DH (2014), the educational environment can be used as a driving force to develop children's creativity. States that basic movement is the basis for learning and developing various technical skills in sports and physical activities for life. therefore, If the child's basic movement competence is not developed, they fail to use various sports and game skills in their childhood and adolescence (Pangrazi and Beighle, 2019).

The limit of this study is only covering the student's psychomotor. So that for the future research, to improve or develop basic movement skills can be combined with the form of the game. At their age, children prefer to learn while playing because they can discover new things. They can explore, imitate, and practice everyday life as a step in building skills to help themselves. Play is an important activity in child development and is very important for a child to reach his full potential (Moore, 2017). Play is the nature of children (children's work). Play is important for children's development because of its impact on their cognitive, physical, social development and emotional health (Herrington and Brussoni, 2015).

\section{Conclusions}

Descriptive analysis of physical activity in developing students' basic movements was carried out with descriptive statistics, namely describing the data that has been obtained with the minimum, maximum, mean and standard deviation values. The minimum value for the buying interest vari- able is 2.78 , the maximum value is 5.00 and the standard deviation value for this variable is 0.47 . While the average value for the physical activity variable is 4.205 , which if categorized includes physical activity in developing students' basic movements in the very good category. For physical activity variables in developing students' basic movements,

From the results of the analysis, the table results show that each item of the statement of the physical activity variable in developing students' basic movements, the average respondent assesses physical activity in developing students' basic movements with an average value with all the statements submitted, this can be seen from the average value of 4.205 which is in the very good category scale range. The statement that has the smallest average value in statement number 2 is "Students do enough physical activity at school?" has a value of 3.827 with a good category. While the highest average in statement number 1 is "Kindergarten students' physical activities are held at school?" with an average value of 4.423 very good category.

Kindergarten (PAUD) is one form of early childhood education unit in the formal education path for children aged four to six years. The purpose of Kindergarten (PAUD) education is to develop all potential from an early age, so that children develop naturally in achieving success in the future. The reality of education in early childhood is still applying a rote academic approach. Practices that are in accordance with the needs/development of children (developmentally appropriate practice) have not been fully implemented or have not been able to accommodate the needs of each individual to grow optimally or do not sufficiently provide space for the uniqueness of each individual. One way to develop basic movements in early childhood in kindergarten (PAUD) This can be done with physical literacy so that children are able to participate and have advantages in physical activities and sports. The issue of the importance of movement activities in the community around us is still something that is considered lacking. Physical literacy is according to the ability of each individual, physical literacy is physical literacy that can be described as motivation, self-confidence, physical competence, knowledge and understanding to maintain physical activity throughout life. Physical literacy provides insight, experience, competence, motivation in children so that children have sufficient "treasury" of movement as provisions for later active life throughout life. The concept of Physical Literacy is a strong foundation for children to be able to participate and have advantages in physical activities and sports. Literacy on movement will be able to form awareness of the importance of physical activity for the younger generation, become a lifestyle and be able to develop personal potential. It is proven in this study, the physical activity model to develop basic movement skills of kindergarten students gets good results and is very useful for early childhood.

\section{Acknowledgement}

This research is supported by Universitas Sebelas Maret and Yogyakarta State University

\section{Conflict of interest}

We know of no conflicts of interest associated with this publication, and there has been no significant finan- 
cial support for this work that could have influenced its outcome.

\section{References}

Suherman, W. S. (2017). Pengembangan "Majeda” Berbasis Dolanan Anak untuk Pengoptimalan Tumbuh Kembang Siswa Taman Kanak-kanak. Jurnal Cakrawala Pendidikan, 36(2). https://doi.org/10.21831/cp.v36i2.13542

Arsana, I. M., Susila, I. W., Hidayatullah, R. S., \& Ariyanto, S. R. (2019). Implementation of Troubleshooting Teaching Method to Develop Student's Competency in Conducting Motorcycle Tune-up. Journal of Physics: Conference Series, 1387(1), 012096. https://doi.org/10.1088/1742-6596/1387/1/012096

Pangrazi, R. P., \& Beighle, A. (2019). Dynamic physical education for elementary school children. Human Kinetics Publishers.

Hijriati, H. (2019, May). The use of Tahfidz Go Game to Improve the Intelligence of Children. In International Conference on Early Childhood Education (pp. 64-70).

Nasrulloh, A., Prasetyo, Y., Nugroho, S., Yuniana, R., Pratama, K. W., Mustapha, A., \& Idrus, S. Z. S. (2020). Tricet Method to Increase the Hypertrophy Muscle. Journal of Physics: Conference Series, 1529(3), 032006.

https://doi.org/10.1088/1742-6596/1529/3/032006

Putra, K. W. P., Gustiawati, R., \& Julianti, R. R. (2020). Survei Pembelajaran Pendidikan Jasmani Yang Menyenangkan Bagi Peserta Didik SMP. Jurnal Pendidikan Olah Raga, 9(2), 170-180.

Sutapa, P., Prasetyo, Y., Pratama, K. W., Karakauki, M., Mustapha, A., \& Idrus, S. Z. S. (2020). Motor Development Index (MDI) Based on Combination of Human Development Index (HDI) and Sport Development Index (SDI) as a Success Parameter of Motor Development among Preschool Children: An Observational Study. Journal of Physics: Conference Series, 1529(3), 032003.

https://doi.org/10.1088/1742-6596/1529/3/032003

Skinner, A. C., Ravanbakht, S. N., Skelton, J. A., Perrin, E. M., \& Armstrong, S. C. (2018). Prevalence of Obesity and Severe Obesity in US Children, 1999-2016. Pediatrics, 141(3), e20173459. https://doi.org/10.1542/peds.2017-3459

Kremer, K. P., Flower, A., Huang, J., \& Vaughn, M. G. (2016). Behavior problems and children's academic achievement: A test of growth-curve models with gender and racial differences. Children and Youth Services Review, 67, 95104. https://doi.org/10.1016/j.childyouth.2016.06.003

Sun, H., Li, W., \& Shen, B. (2017). Learning in Physical Education: A Self-Determination Theory Perspective. Journal of Teaching in Physical Education, 36(3), 277-291. https://doi.org/10.1123/jtpe.2017-0067

Donnelly, J. E., Hillman, C. H., Castelli, D., Etnier, J. L., Lee, S., Tomporowski, P., Lambourne, K., \& Szabo-Reed, A. N. (2016). Physical Activity, Fitness, Cognitive Function, and Academic Achievement in Children: A Systematic Review. Medicine \& Science in Sports \& Exercise, 48(6), 1197-1222.

https://doi.org/10.1249/MSS.0000000000000901
Marttinen, R. H. J., McLoughlin, G., Fredrick, R., \& Novak, D. (2017). Integration and Physical Education: A Review of Research. Quest, 69(1), 37-49. https://doi.org/10.1080/00336297.2016.1150864

Brusseau, T. A., \& Hannon, J. C. (2015). Impacting Children's Health and Academic Performance through Comprehensive School Physical Activity Programming. International Electronic Journal of Elementary Education, 7(3), 441-450.

Kristiyanto, A., Prasetyo, Y., Pratama, K. W., Karakauki, M., Mustapha, A., \& Idrus, S. Z. S. (2020). Access to The Utilization of Science and Technology of Sports and Familiarity of the Sports Community towards Technologically Based Devices. Journal of Physics: Conference Series, 1529(2), 022099. https://doi.org/10.1088/1742-6596/1529/2/022099

Nugroho, S., Nasrulloh, A., Karyono, T. H., Dwihandaka, R., \& Pratama, K. W. (2021). Effect of intensity and interval levels of trapping circuit training on the physical condition of badminton players. Journal of Physical Education \& Sport, 21. https://doi.org/10.7752/jpes.2021.s3252

Mashud, S. H., \& Abdillah, S. (2021, April). Physical Literacy: Kajian Sarpras Pendukung Pembelajaran Pjok Dan Ektrakurikuler Olahraga Di Sekolah Daerah Lahan Basah. In Prosiding Seminar Nasional Lingkungan Lahan Basah, 6(2).

Ginanjar, A., Suherman, A., Juliantine, T., \& Hidayat, Y. (2020). Model Pendidikan Olah Raga Berbasis Keterampilan Gerak Dasar. Jurnal Kependidikan: Penelitian Inovasi Pembelajaran, 4(1), 43-54. https://doi.org/10.21831/jk.v4i1.24410

Andrian, R., Suroto, S., Tuasikal, A. R. S., Dhani, S. S. S., \& Setyorini, S. (2020). Efektivitas Model Pembelajaran Motorik Berbasis Movement Based Games Pada Siswa Sekolah Dasar. JOSSAE: Journal of Sport Science and Education, 5(1), 64. https://doi.org/10.26740/jossae.v5n1.p64-74

Gustian, U., Supriatna, E., \& Purnomo, E. (2019). Efektifitas modifikasi permainan tradisional dalam pengembangan physical literacy anak taman kanak-kanak. Jurnal Keolahragaan, 7(1), 23-33. https://doi.org/10.21831/jk.v7i1.22166

Ismoko, A. P., \& Putro, D. E. (2016). Model Pengenalan Aktivitas Jasmani Bagi Siswa Taman Kanak-Kanak. Jurnal Humaniora, 4(1), 418-424.

Pusari, R. W., \& DH, D. P. (2014). Increasing Creativity on Early Childhood Education Teachers through Educational Toys. Indonesian Journal of Early Childhood Education Studies, 3(2), 108-113.

Moore, R. C. (2017). Childhood's domain: Play and place in child development (Vol. 6). Routledge.

Haapala, E. A. (2013). Cardiorespiratory Fitness and Motor Skills in Relation to Cognition and Academic Performance in Children - A Review. Journal of Human Kinetics, 36(1), 55-68. https://doi.org/10.2478/hukin-2013-0006

Herrington, S., \& Brussoni, M. (2015). Beyond Physical Activity: The Importance of Play and Nature-Based Play Spaces for Children's Health and Development. Current Obesity Reports, 4(4), 477-483. https://doi.org/10.1007/s13679-015-0179-2 


\title{
МОДЕЛЬ ФІЗИЧНОЇ АКТИВНОСТІ ДЛЯ РОЗВИТКУ БАЗОВИХ РУХОВИХ НАВИЧОК У ВИХОВАНЦІВ ДИТЯЧОГО САДКА НА ОСНОВІ ФІЗИЧНОÏ ГРАМОТНОСТІ
}

\author{
Аріс Фаджар Памбуді ${ }^{1,2 A B C D E}$, Сугіянто ${ }^{1 \mathrm{ACDE}}$, \\ Фуркон Хідаятулла ${ }^{1 \mathrm{ABCE}}$, Сапта Кунта Пурнама ${ }^{1 \mathrm{BCDE}}$ \\ ${ }^{1}$ Університет Себелас Марет \\ ${ }^{2}$ Університет Негері Джок'якарта \\ Авторський вклад: А - дизайн дослідження; В - збір даних; C - статаналіз; D - підготовка рукопису; Е - збір коштів \\ Реферат. Стаття: 7 с., 5 рис., 9 табл., 24 джерел.
}

Брак фізичної активності в дитячому садку (у дошкільній освіті) погано впливає на майбутнє дітей. Виявлено, що розроблена навчальна програма приділяє більше уваги розвитку академічної успішності.

Мета дослідження - формування базових рухових навичок у вихованців дитячого садка на основі фізичної грамотності.

Матеріали та методи. У роботі застосовано методи дослідження та розробки з використанням кількісних та якісних параметрів. 3-поміж усіх 1387 вихователів із 350 дитячих садків в окрузі Чилачап використовувалася вибірка з 52 вихователів, обраних шляхом пропорційного відбору. У дослідженні використано описові кількісні методи аналізу даних з відсотками.

Результати. Результати дослідження показують, що кожен пункт формулювання змінних фізичної активності у розвитку основних рухів вихованців можна по- бачити із середнього значення 4,205, що знаходиться в дуже хорошому діапазоні шкали категорій. Пунктом 3 найменшим середнім значенням у твердженні № $2 €$ «Чи достатньо учням фізичної активності в школі?», його значення становить 3,827 та відноситься до хорошої категорії. Тоді як найвищим середнім значенням у твердженні № $1 €$ «Чи проводяться заняття з фізкультури для вихованців дитсадка в школі?», його середнє значення становить 4,423 та відноситься до дуже хорошої категорії.

Висновки. Отже, можна зробити висновок, що «заняття $з$ фізкультури для вихованців дитсадка, які проводяться в школах», справляють дуже гарне враження та $€$ корисними для росту та розвитку дітей дитячого садка (у дошкільній освіті).

Ключові слова: фізична активність, основні рухові навички, дитячий садок, фізична грамотність.

\section{Information about the authors:}

Pambudi Aris Fajar: arisfajarpambudi@student.uns.ac.id; https://orcid.org/0000-0002-0819-7894; Sebelas Maret University; Jl. Menteri Supeno, Manahan, Banjarsari, Kota Surakarta, Jawa Tengah 57139, Indonesia.

Sugiyanto: sugiyantoprobo@gmail.com; https://orcid.org/0000-0002-9991-5264; Sebelas Maret University; Jl. Menteri Supeno, Manahan, Banjarsari, Kota Surakarta, Jawa Tengah 57139, Indonesia.

Hidayatullah Furqon: furqon@fkip.uns.ac.id; https://orcid.org/0000-0001-8862-5862; Sebelas Maret University; Jl. Menteri Supeno, Manahan, Banjarsari, Kota Surakarta, Jawa Tengah 57139, Indonesia.

Purnama Sapta Kunta: saptokunto.p@gmail.com; https://orcid.org/0000-0001-7198-1385; Sebelas Maret University; Jl. Menteri Supeno, Manahan, Banjarsari, Kota Surakarta, Jawa Tengah 57139, Indonesia.

Cite this article as: Pambudi, A.F., Sugiyanto, S., Hidayatullah, F., \& Purnama, S.K. (2021). Physical Activity Model to Develop Basic Movement Skills in Kindergarten Students Based on Physical Literacy. Teoriâ ta Metodika Fizičnogo Vihovannâ, 21(4), 323329. https://doi.org/10.17309/tmfv.2021.4.06

Received: 09.09.2021. Accepted: 28.10.2021. Published: 25.12.2021

This work is licensed under a Creative Commons Attribution 4.0 International License (http://creativecommons.org/licenses/by/4.0). 